\title{
Benjamin Harrison, Ideas, and the Seeds of Economic Crisis: 1889-1893
}

\author{
September 11, 2020 \\ Paper presented at the \\ 2020 American Political Science Association \\ Annual Conference
}

\author{
By \\ Mark Zachary Taylor \\ Associate Professor \\ School of Public Policy \\ Georgia Institute of Technology \\ 685 Cherry St NW \\ Atlanta, GA 30332-0345 \\ (FedEx/UPS Zip Code: 30318) \\ contact: mzak@gatech.edu
}

\begin{abstract}
What role does the US president, and their political ideology, play in fostering destabilizing political-economic crises? This paper examines the little-studied presidency of Benjamin Harrison for answers. During the 1890s, the US suffered its worst financial crisis and economic depression to date. The Democratic party fractured. Anarchists, socialists, and other anti-democratic groups enjoyed a resurgence. Violent labor uprisings plagued the nation's rails, factories, and mines. From this chaos emerged a powerful inflationist movement, led by a norm-busting demagogue, who was ultimately only defeated by the champion of the longest protectionist trade regime in US history. Surprisingly, the seeds of this crisis were laid by the strangely inconsistent policies of the Harrison administration. Benjamin Harrison was, by most measures, supremely equipped to deliver a booming economy. He was college educated and, for his time, exceedingly well-versed in political-economy. He was also a devoted public servant, with decades of leadership experience and considerable background in public policy and legislative affairs. In public administration, Harrison was one of the most competent executives ever to enter the White House. He was also a formidable campaigner, and yet, a paragon of decency in an indecent era. However, instead of prosperity, Harrison created the conditions for a devastating financial crisis and a deep recession. This paper shows how Harrison's political ideas resulted in a haphazard mixture of fiscal, trade, and monetary policies that caused a sudden spike in spending accompanied by a rapid decrease in tax revenues that sent the country from surplus into deficit. Harrison's curious instability on monetary policy then scared investors into fleeing a potential dollar devaluation. When bad harvests and an economic slowdown hit during mid-1892, conditions gradually snowballed into a financial panic and the Great Depression of 1893-1897 that commenced soon after he left office. Harrison's ideology and beliefs drove his actions as president, and were the sin qua non of this political-economic disaster. This case therefore has important implications for theories of presidential power, American political development, partisanship, democratic governance, and the role of ideas in politics.
\end{abstract}




\section{Introduction}

What role does the US president, and their political ideology, play in fostering destabilizing politicaleconomic crises? This paper examines the little-studied presidency of Benjamin Harrison for answers. During the 1890s, the US suffered its worst financial crisis and economic depression to date. The Democratic party fractured. Anarchists, socialists, and other anti-democratic groups enjoyed a resurgence. Violent labor uprisings plagued the nation's rails, factories, and mines. From this chaos emerged a powerful inflationist movement, led by a norm-busting demagogue, who was ultimately only defeated by the champion of the longest protectionist trade regime in US history.

Surprisingly, the seeds of this crisis appear to have been laid by the strangely inconsistent policies of the Harrison administration. It constitutes a "most-likely" case in that Benjamin Harrison was, by most measures, supremely equipped to deliver a booming economy. He was college educated and, for his time, exceedingly well-versed in political-economy. He was also a devoted public servant, with decades of leadership experience and considerable background in public policy and legislative affairs. In public administration, Harrison was one of the most competent executives ever to enter the White House. He was also a formidable campaigner, and yet, a paragon of decency in an indecent era. However, instead of prosperity, Harrison may have created the conditions for a devastating financial crisis and a deep recession. This paper shows how Harrison's political ideas resulted in a haphazard mixture of fiscal, trade, and monetary policies that caused a sudden spike in spending accompanied by a rapid decrease in tax revenues that sent the country from surplus into deficit. Harrison's curious instability on monetary policy then scared investors into fleeing a potential dollar devaluation. When bad harvests and an economic slowdown hit during mid-1892, conditions gradually snowballed into a financial panic and the Great Depression of 1893-1897 that commenced soon after he left office. Harrison's ideology and beliefs drove his actions as president, which were arguably the sin qua non of this political-economic disaster. In making this argument, this paper also contends that the supposedly "lost" and irrelevant presidents of the Gilded Age, "none of them seemingly worth remembering for any substantial achievement", were far more capable and potent than conventionally thought (Wolfe 1934, 103; White 2017, 3). This case therefore has important implications for theories of presidential power, American political development, partisanship, democratic governance, and the role of ideas in politics.

\section{Background}

Benjamin Harrison was as close as anyone might come to being American aristocracy. He was son of a US congressman, grandson of the ninth President, and great-grandson of a signatory to the Declaration of Independence. Yet, he benefited little from his family pedigree. Though born in his illustrious grandfather's house in Ohio in 1833, his own father was a middle-class farmer who grumbled "My lot in this life has been to raise hogs and hominy to feed my children" (Sievers 1960, 21). Benjamin's mother was also middle-class, descended from low-level Scottish nobility, the daughter of a miller and merchant. Thus Harrison was "a farmer's boy, lived in a little farm house, had to hustle out of bed between 4 and 5 o'clock in the morning the year round to [do his chores]" according to one contemporary (ibid., 23).

Harrison was also one of the most intelligent and well-educated presidents of the $19^{\text {th }}$ century. His parents believed deeply in education. As a boy, he was provided with a steady stream of tutors to supplement the local log-cabin schoolhouse. Then, at age fourteen, Harrison entered the Presbyterian Farmers' College near Cincinnati, a small, but surprisingly advanced, institution. Its curriculum was designed, in part, by a highly respected professor of history and political economy, who personally taught Harrison about government and social relations (Huston, 1909). ${ }^{1}$ After two years, Harrison transferred to the esteemed Miami University (of Ohio) in order to court his future wife. Again, religious instruction and scientific interpretation were central to the school's courses on history, politics, and political-economy (Havighurst 1958, 46). ${ }^{2}$ Thus, overall, Harrison received a full education, rare in its day, in political economy, but one geared towards understanding government as an organic, liberalizing instrument of the people that should foster "the growth or development of civil and religious liberty", rather than dry, technical discussions of trade or finance (Rodabaugh 1935, 132). Harrison was judged by his classmates "an unpretentious but courageous student" often "respectable" if not "excellent" in his studies (Sievers 1960, 52). He also mastered public speaking, and was invited to lecture on political-economy at his own graduation (Ross 1892). ${ }^{3}$

A sincerely devoted Presbyterian, Harrison considered pursuing the priesthood after college, but chose law instead. Harrison studied law under a prominent Ohio attorney and former congressman at a law firm in 
Cincinnati. By early 1854, Harrison earned admission to the bar. He promptly left Cincinnati, moving with his new wife and child to the small but blossoming city of Indianapolis. After a year of struggling, Harrison was invited into a law partnership with the son of the state's governor. "[H]e worked like a slave" attested his law partner, who dedicated his own time to the new Republican Party (Sievers 1960, 108). As a result of Harrison's labors, the firm flourished, as did Harrison. At home, the Harrisons, both "serious young people", intensified their Presbyterian faith, centering their lives around their church (ibid., 55). Harrison became a Sunday school teacher, and "was constant in his attendance on church services" (ibid., 113). Over time, Harrison also became a church deacon and a church elder, and he kept religion the focal point of his everyday life until he died.

Though from a prominent political family, Harrison did not yet participate much in party politics. Perhaps because his own father, by now in Congress, warned him that "none but knaves should ever enter the political arena" (Sievers 1960, 117). After considerable thought and close attention to the political scene, young Harrison's increasingly strong anti-slavery views led him into the new Republican party during 1856 (ibid.). ${ }^{4}$ His religious and political beliefs began to merge. He saw the Republicans as fighting for man's God-given liberties. To him, the Republicans had come together to wage a desperate battle against the political-economic backwardness of the dangerous "slave oligarchy and the slave aristocracy" which ruled the South (ibid., 147). Although he lacked social finesse, Harrison was an adept orator. He backed John Fremont, the Republican presidential candidate, as a busy stump speaker in that year's election. "I am Fremont all over and all the time..." he proclaimed to a friend (ibid., 125). ${ }^{5}$ The following year, Harrison himself ran for office, and won election as the city attorney of Indianapolis. He continued to do party and legal work for the Republicans in Indianapolis until the outbreak of the Civil War.

Harrison supported the war, and Lincoln, from the start, calling the president a "great simple hearted patriot" (Harrison 1901, 473). He stumped for Lincoln's election and excoriated the South, swearing that he would "never, by word or thought, by mind or will, aid...the Everlasting Curse of Human Bondage" (Calhoun 2005, 20). In summer 1862, as the war dragged on, Harrison was prompted "by a high sense of Christian patriotism" to enlist in the Union Army when entreated by state's governor (Ringenberg 1986, 179). He volunteered to raise and train an Indiana regiment, despite having no military experience himself. Six months later, assigned the rank of Colonel, he led them into three years of combat.

Over the course of the war, Harrison's regiment fought over thirty battles throughout Kentucky, Tennessee, and Georgia, eventually earning him promotion to brevet Brigadier General. He saw a divine aspect to the war, describing himself as "a good soldier of Jesus Christ" fighting "to honor my country and my friends" (Sievers 1960, 190). By most accounts, Harrison was a strict, but able, commander who courageously led from the center of the action, and participated in every aspect of combat, from daily drills to logistics, even battlefield surgery when necessary. He left the army a well-respected hero, and much admired by the men who served with him. And yet, Harrison was glad to be discharged when the war ended. "I am not a Julius Ceasar, nor a Napoleon..." he wrote his wife from the field, "[I have] no more relish for a fight than for a good breakfast" (Sievers 1960, 264). Nevertheless, he resented those who had avoided military service, declaring "I really begin to feel contempt for those who talk so eloquently for the Union and won't come and fight for it" (ibid., 273). Harrison's distaste for the South and its sympathizers would prove an enduring disposition throughout his political career.

After the war, Harrison declined invitations to run for Congress. "[I]t would take me away from home so much..." he explained to his wife, "I certainly long only for a quiet usefulness at home" (Ringenberg 1986, 180). Instead, he returned to his family and law practice in Indianapolis. He and his wife also became heavily involved in community work, as well as church and veterans' groups. This inclination towards a tranquil life of home, church, and office, over politics, would become another lifelong tendency for Harrison. He seems to have enjoyed speech-making and administrating, but he "disliked politicians," and often treated them "in a very chilly manner" (Mayer 1964, 221; Ellis 2008, 100).

The war also deepened Harrison's loyalty to the Republican party. For years, he remained furious at the disloyalty of the Confederates, as well as the Peace Democrat "Copperheads" in Indiana, who had undermined him at home while he was away in battle (Sievers 1960, 136-137, 208-209). ${ }^{6}$ He long insisted that "I am willing to forget that they were rebels, at least as soon as they are willing to forget it themselves", but for Harrison, that time never seemed to come (Hedges 1892). ${ }^{2}$ He therefore backed the Radical Republicans, and their stern 
political punishments for ex-confederates; though he gradually softened, adopting more moderate, mainstream Republican political-economic views over time. He attempted to run for governor of Indiana in 1872, but the state's Republican party bosses failed to back his nomination (Calhoun 2005). ${ }^{7}$ The following year, the Panic of 1873 shook the Indianapolis economy; though Harrison's law office prospered thanks to the steady flow of bankruptcy, foreclosure, and delinquency cases that resulted. Around this time, Harrison also won some highprofile legal cases, which brought him national attention. All the while, he continued to energetically work for the Republican party, which he still saw as the paramount defender of American liberties and progress.

In autumn 1876, state Republican leaders drafted Harrison as a last-minute, substitute candidate to run for Governor of Indiana. Harrison lost, but just barely. And he proved an enormously popular speech-maker during the campaign. Years later, an old Washington politico, who heard every president speak from Lincoln to Coolidge, attested that "none of them equaled [Harrison] as an orator" (Depew 1923, 140). Even critics admitted that "if [Harrison] should address ten thousand men from a public platform, he would make everyone one his friend" (Cullom 1911, 248). During the next few years, the national Republican party featured Harrison as a speaker in cities around the eastern and central states, campaigning for Republicans of all ranks. Harrison also worked on state and national issues. When violent railroad strikes reached Indianapolis during the explosive summer of 1877, he helped to organize a peaceful resolution. He served on the federal Mississippi River Commission, earning the admiration of President Hayes (1877-1881), who thought Harrison "a firm, sound man; his personal character is clear and high." (Hayes 1888) Harrison dined at the White House and even hosted Hayes in his Indianapolis home.

By 1880, thanks to his activism and distinguished reputation, and the death of a jealous political boss, Harrison had risen to become the Republican party leader in Indiana (Fuller 2017). He now finally ran for US Senate which, at that time, meant lobbying the state legislature for appointment. The seat was easily won by Harrison. Senator Harrison then served in Washington from 1881-1887. There he specialized in problems of Indian Affairs, the West, transportation, and military veterans. He strongly supported federal aid for veterans and tried to advance legislation to protect the nation's natural resources. But otherwise, Harrison mostly voted along the Republican party lines, and against hated Democrats. When Democrats increased their power in the Indiana state government, he lost reappointment after a difficult political battle, and departed the Senate.

\section{Election}

By 1888, the Republicans desperately needed a clean candidate, and one independent of the party's jealous factions, to take back the White House from Democrat Grover Cleveland. Harrison was not the Republican party's top choice (Calhoun 2008). However, more senior candidates either declined to run, were "wrong" on important issues (i.e. tariffs, veterans' pensions), or came from electorally unimportant states. In contrast, Harrison was a Union Army general, a respected Senator, and heralded from the pivotal state of Indiana. He had also spent decades promoting party unity and patriotism, rather than divisive policies. On the issues, he was pro-pension, leaned pro-tariff, and was quietly moderate on silver. He was also well-regarded by senior Republicans and an excellent public speaker. So, after considerable jousting at the party convention with Ohio Senator and ex-Treasury Secretary John Sherman, Harrison won the Republican nomination on the eighth ballot (Calhoun 2008). ${ }^{9}$

Harrison was an avid campaigner, aided by a passionate and competent team of Republican political bosses. They knew how to win elections, and fought hard and dirty to do so. Many Republicans saw Democrats not just as political rivals, but as enemies of American values and progress. Recognizing that open campaigning was still considered too bold and undignified, Harrison launched a clever "front porch" campaign (Socolofsky and Spetter 1987, 11; Bourdon 2019). ${ }^{10}$ Important interest groups and curious voters were brought to Harrison's home in Indianapolis, where he addressed the crowds, often in customized speeches informed by campaign research. He gave over 90 different campaign speeches from memory. These speeches were then printed in papers nationwide, reaching millions of voters. In them, he capitalized on the disastrous "Great Tariff Debate" launched by President Cleveland and pounded away in support of trade protectionism. Large industrial interests, such as steel, iron, and manufacturing firms seeking protection, donated in record amounts to elect Harrison, in what future muckraker Ida Tarbell called a "campaign for protection backed by the protected" (C. Johnson 2018, 121). Meanwhile, Republican spoilsmen spared neither fraud, threat, nor bribe to win votes, desperate to regain Republican control over federal jobs and government contracts. 
That November, Benjamin Harrison defeated Grover Cleveland thanks to a handful of votes in pivotal states. In fact, thanks to voter suppression in the South, Cleveland won the popular vote that year (Calhoun 2008; HSUS 2006) ${ }^{11}$ but he lost the Electoral College by narrow margins in New York and Indiana. ${ }^{12}$ Third parties acted as spoilers in some states: the Prohibition Party captured nearly a quarter million votes $(2.2 \%$ of the popular vote), as the anti-saloon movement gained steam; while two labor parties based in the Midwest together brought in around 150,000 votes (1.3\% of the popular vote). Republicans also managed to deliver razor thin majorities in Congress. Thus, if Harrison and the Republicans could work together, they had a rare opportunity to pass whatever agenda they might agree upon. And Harrison was eager to forge those agreements.

\section{Harrison's Vision}

However, Harrison seemed to lack a clear, coherent vision for the country (see also Calhoun 1993, 651667). Instead, he appears to have been guided primarily by his desire to unify and strengthen the Republican party, in the belief that it remained locked in battle with backward-looking Democrats whose anti-federal policies were "dangerous heresy, and a deadly poison to national life" (Sievers 1960, 275). Although the guns of the Civil War had fallen silent in 1865, Harrison believed that "beaten by the sword, [the Confederates] will now fall back on the 'resources of statesmanship.'... they will steal away, in the halls of Congress, the fruits won from them at the glistening point of the bayonet" (Sievers 1959, 13-14). His prediction proved correct. During the 1870s, Southern Democrats proceeded to suppress the black vote, block the admission of new states, and were suspected of manipulating elections in the North and West (Hedges 1892). To Harrison, they seemed intent on keeping the US trapped in the past, as an agricultural economy run by wealthy white planters. By the 1880s, he had come to view Democrats as the enemies of democracy and "the boulder in the stream of progress, impeding and resisting its onward flow" (ibid.). The best and only defense against them was the "high atmosphere of patriotism and pure Republicanism" (ibid.).

Thus party unity and loyalty were often more important to Harrison than policy or economic philosophy. As president, he did embrace the fiery brand of economic nationalism and trade protectionism that the Republican party had inherited from the Whigs, and which consumed the party during the 1880s and 1890s. Harrison had always leaned in this direction. But it was party unity that thrust it to his top priority. And satisfying Republican legislators and interest groups in order to stop the Democrats did not result in a consistent vision for the country. Here he differed drastically from his presidential rival, Grover Cleveland, who cared much for strict Constitutionalism and laissez-faire minimalism, but little for his party. ${ }^{13}$ Even years into retirement, and amidst a national economic crisis, Harrison continued to insist to fellow party members that "[w]e ought not...to be asked to do anything that will affect the solidity, the loyalty, the discipline or the enthusiasm of the Republican party." 14

Even Harrison's few consistent policy positions appear driven by his fierce partisan loyalty and his "high sense of Christian patriotism". For example, he regularly advanced Northern interests at the expense of the South. He routinely insisted that Union veterans be recognized and rewarded for their service. His Presbyterian upbringing led him to stubbornly oppose cuts in alcohol taxes, then a major source of federal revenues (HSUS 2006).${ }^{15} \mathrm{He}$ also believed that America's natural resources were given by God, and should therefore be conserved. And his Whig tendencies told him that government should help fund education and infrastructure (Sievers 1959; Graham 2015).

But Harrison's party loyalty failed to provide him much direction on specific economic issues like tariffs, currency, monopolies, etc. Instead, he tended to straddle the fence on major political-economic debates. For example, despite his support for the Civil War and emancipation, Harrison was initially lukewarm on citizenship for freed slaves. Over time, he increasingly favored civil rights for African-Americans, but he led no great legislative battles for them while in Congress. On the spoils system, he stridently supported civil service reform in his speeches and writings, but then ignored reform when asked to find federal jobs for veterans and political allies. "[Harrison] used, but sincerely believed that he did not abuse, the spoils system," writes one biographer, "To him it was a distasteful necessity..." (Sievers 1959, 220). Harrison spoke out courageously against railroad monopolies, yet happily accepted their campaign donations and travel passes, and he prosecuted few corporate monopolies while in office. In regards to striking workers, he declared "I am sympathetic with the laboring man and I shall always be found supporting such measures as are for his interest" (ibid., 284). But he also insisted that the United States was already "a land that throws about the workingman social and political conditions more favorable than are found elsewhere" (Hedges 1892, 61). Hence he did little of substance to help 
labor while in office. He once blamed the impoverishment of Britain's lower-classes on government welfare (Sievers 1960, 65). ${ }^{16}$ And yet he supported vast federal expenditures on welfare for Union army veterans and their dependents, despite clear evidence of fraudulent claims (Sievers 1959, 210). He also supported federal investment in national infrastructure, but then got distracted by the legal details (Sievers 1959). Nor did he take a clear stand in the heated immigration debates of the era, choosing instead to quibble over the constitutional aspects of immigration law.

Trade was perhaps the pivotal economic issue for Harrison's election and presidency. But over his career, his support for tariffs was uneven. He generally favored tariffs that protected American industries, but his reasoning could be tortured and illogical:

"If the tariff were lowered, our mills would close and English goods would come in, but there would be less goods all around; there would be more demand for the goods; the price would go up; and we would be just as badly off as we were before, except that the Englishman would have all the business, and our workers would be unemployed" (Latham 1939, 30). ${ }^{17}$

To labor audiences, he then argued that lower tariffs hurt wages by lowering prices; yet, he simultaneously denied that higher tariffs drove up domestic prices much. In fact, he once mocked critics of tariff inflation, somewhat ridiculously, by saying that he was not in "sympathy with this demand for cheaper coats, which seems...necessarily to involve a cheaper man and woman under the coat." (Hedges 1892) And yet, despite all this, Senator Harrison had voted to reduce tariffs as politics demanded (Sievers 1959, 210-214, 227-228).$^{18}$ Only when Republicans made higher tariffs the wedge issue for the 1888 election did Harrison lead the fight in support of protectionism (Hedges 1892, 179). ${ }^{19}$

On the equally crucial issue of money, Harrison could also be found on all sides of the debate. He reliably emphasized a "sound currency" in his speeches and writings; but, depending on the audience or situation, he might praise or criticize any type of money, while ironically attacking his opponents for inconsistency. ${ }^{20}$ To gold men, he acknowledged that "free coinage of silver under existing conditions would disastrously affect our business interests...[and] produce a commercial panic.” (Woolley and Peters n.d.) To silverites, he declared "I have been an advocate of the use of silver in our currency. We are large producers of that metal, and should not discredit it." (Woolley and Peters n.d.) To attract the Greenback vote, he insisted that "The greenback is a promise on the part of the government to pay money... [and it] is a currency with which I believe the people will never consent to part." 21 To still others he claimed "I have always believed, and do now more than ever believe, in bimetallism, and favor the fullest use of silver in connection with our currency that is compatible with the maintenance of the parity of the gold and silver dollars in their commercial uses" (Hedges 1892, 289). Harrison was likely being honest, not duplicitous. He seemed to believe that gold, silver, and greenbacks could somehow co-exist. But such diverse positions were not just untenable, they were economic contradictions. ${ }^{22}$ Harrison was no inflationist, but he exhibited no specific, consistent beliefs on currency (Socolofsky and Spetter 1987).

As for the presidency, Harrison had a similarly inconsistent approach. As "ever the Whig at heart", Harrison let legislation originate in Congress, but he provided input and applied pressure on a level hitherto unseen in $19^{\text {th }}$ century presidents (Socolofskyand Spetter 1987, 47). On executive matters, and even much legislation, he did not take advice well. Harrison diplomatically sought input from cabinet members on bills that concerned their particular departments, but he rarely acted on it. He "was of a deliberative habit of mind and not only took his own time but kept his own counsel" said one of his senior appointees (Sievers 1968, 4). ${ }^{23}$ Harrison also viewed the president as a national cheerleader, thus he traveled the country giving dozens of speeches praising the nation, the US Constitution, and the American flag.

In foreign policy, Harrison was far more nationalistic, bold, and confrontational than his recent predecessors. He was no imperialist. But Harrison wanted to see the US respected alongside the European great powers. Thus, the Harrison administration sought to control new territories (Hawaii, Samoa), replace Britain as the primary military and economic power in the Western Hemisphere, and establish US naval stations in the Pacific. Harrison also tended to be uncompromising in his negotiations with foreign governments, even using implicit threats of military force to resolve issues with Chile, Italy, Canada, and Great Britain.

Over time, Harrison proved to be one of the most "hands-on" presidents in American history. "Harrison knew more about the workings of the various departments than did their various heads..." remarked one advisor 
(ibid., 276). He also refused to delegate much. He had "a profound sense...that he himself could best guide the ship of state" (ibid., 5). So, he not only oversaw Federal appointments, but he also assisted each cabinet member in determining their department's policies. At various points in his term, Harrison even took over the Departments of State, Treasury, Interior, Navy, and War when those Secretaries fell ill or were incapacitated. Thus, on many issues, for all intents and purposes, Harrison was the executive branch.

\section{9: Harrison's Honeymoon Year}

President Harrison's first year in office was relatively quiet. The economy fared well and there was little urgent economic business. Nor did critical political matters call for his attention. The incoming $51^{\text {st }}$ Congress was not scheduled to convene until early December, so no new legislation was possible (Calhoun 2005, 83). ${ }^{24}$ Therefore, Harrison spent most of 1889 dealing with appointments, getting his federal departments in order, managing foreign policy (Socolofsky and Spetter 1987; Herring 2008), ${ }^{25}$ organizing the Oklahoma Territory, and tending to ceremonial duties. Perhaps the only exception came in May 1889, when "Central Pennsylvania... was desolated by floods unprecedented in the records of the great waters" after massive rainfalls caused a dam failure that deluged the region (W. Johnson 1889). Over 2,200 people died, 1,600 homes were destroyed, and countless businesses wiped out, while the region's railroad tracks and communication lines were washed away (JAHA 1889). His predecessor, Grover Cleveland, had refused to approve federal aid to help with local catastrophes. But Harrison quickly offered federal assistance, and sent government officials to report on

conditions. Harrison then presided over private fundraising efforts in Washington D.C. that delivered \$30,000 in aid (roughly $\$ 1$ million in 2018 dollars), telling the governor "My heart is burdened for your smitten people" (Mccullough 1987; Williamson 2019; Sievers 1968, 77; Officer 2011). The following year, Harrison visited the region, and was greeted by appreciative crowds. ${ }^{26}$

Civil service reform was the most immediate issue for the new Harrison administration. "Scarcely a day passed without some public debate on spoils versus merit system" notes one scholar (Sievers 1968, 78). Despite considerable progress in civil service reform, competitive exams covered just 18 percent of the almost 160,000 Federal jobs in 1889 (HSUS 2006). ${ }^{27}$ Hence Harrison and his department heads were assailed by thousands of office-seekers and their intermediaries. "I was beset on all sides by dead beats \& incapables" complained a senior party broker (Sievers 1968, 41). With Republicans back in office, and after an election won by historic contributions from wealthy donors, few expected Harrison's independence. Many "dolorously prophesied that [Harrison] would be the tool of [senior Republicans], the obedient servant of the imperious senatorial set... and the victim of faction leaders". After all, the party bosses had been instrumental in getting Harrison elected, and they expected to be rewarded. ${ }^{28}$

But Harrison credited himself, the party, and perhaps divine will, for his election, not individual political machines. From his perspective, the Republicans had desperately recruited him to win an extremely close political battle for the party and country; hence the devoutly religious Harrison owed no one but God for his success. "Providence has given us victory" he proclaimed to friends (Socolofsky and Spetter 1987, 16; Sievers 1959,426$).{ }^{29}$ So he generally ignored the requests of the Republican machine bosses for patronage. And, despite being a former Senator, Harrison also neglected "Senatorial privilege" in his appointments to federal positions outside of Washington (Socolofsky and Spetter 1987). This infuriated Republican spoilsmen, who would mostly abandon Harrison in his 1892 campaign.

Nevertheless, Harrison did play the spoils game. "That would be a fine appointment...but there isn't any politics in it!" he was known to say (ibid., 33). But he played it at his direction, for his political goals. As usual, his primary goal was to unify the Republican party. So, rather than blindly accept the patronage requests from party elites, Harrison personally labored over some 1700 appointments to ensure that Republicans from all geographic wings of the party were appointed to his administration (ibid., 31). He quickly replaced legions of Democrat workers in the Federal government with loyal Republicans. Quality and character mattered. But Harrison made some controversial appointments to high-level patronage spots, like naming a major campaign fundraiser and party operative as Postmaster General. He did appoint a zealous reformer, Theodore Roosevelt, to the Civil Service Commission in charge of reform, but then generally disregarded Teddy's advice (Morris 1979, 441).$^{30}$ Harrison was also seen as being too permissive on the collection of "voluntary" campaign donations by the Republican Party from his appointees (Armbruster 1958). This relapse back into spoils seemed so egregious that, just two months into his presidency, a respected Episcopalian Bishop admonished Harrison in a public 
speech at a national ceremony, warning him against "[t]he conception of the National Government as a huge machine, existing mainly for the purpose of rewarding partisan service" (Potter 1889).

As for Harrison's cabinet, a contemporary journalist later described them as "neither brilliant nor exceptionally strong, and it soon became apparent that Harrison would himself attend to every important matter in the government" (Dunn 1922, 10). Harrison generally did not consider party work, electoral support, or the recommendations of party bosses for his cabinet selections. He mostly selected men older than himself, of solid character, and with considerable experience. The majority of Harrison's cabinet had served in the military, four were US Army generals, most were lawyers, two were businessmen. All were loyal Republicans who agreed strongly with the party platform. All were good church-going Presbyterians. None were from the ex-Confederate South. In fact, most of Harrison's cabinet consisted of men very similar in background and personality to Harrison himself. Still, much like his predecessor's cabinet, they were generally competent administrators and advisors, some were even policy innovators; but only one was a faction head and former party leader. ${ }^{31}$

Meanwhile, as the weather cooled, so too did the economy. The abundant crops of spring and summer resulted in a glut of grains and produce. Wheat prices fell around 25 percent by winter. Prices for beef, pork, corn, barley, and coal also slumped, as did those for steel rails and copper (NBER n.d.). ${ }^{32}$ As a result, deflation returned, around -2.6 percent for 1889, hence real interest rates climbed towards 6 percent (HSUS 2006; NBER n.d.). ${ }^{33}$ The stock market flattened that autumn. Then, the first month of winter brought unusually heavy snow and deep freezes to the West, cutting off transportation and bringing "widespread suffering, attended by appalling losses of livestock" to the region (Oliphant 1932, 4). As a result, markets for transportation and equipment shrank, causing industry to contract sharply. Political pressure built for Congress and Harrison to do something about the economic issues that they had campaigned upon so fiercely.

Thus, after months of relative quiet and intense strategizing, Harrison's early December 1889 message to Congress was a widely anticipated declaration of the Republican agenda for the 1890 legislative session. After a long section reporting on foreign policy, Harrison recommended pages of legislative action: higher tariffs, a stronger military, new spending on river and harbor infrastructure, the first federal anti-trust law, international copyrights, tighter immigration restrictions, a national bankruptcy law, comprehensive federal pensions for Union veterans and their dependents, the admission of new states, federal safety regulations for rail workers, civil rights protections for African-Americans, and more. He also used the message to scold pro-gold, hard-money supporters. He chided them that the "evil anticipations which have accompanied the coinage and use of the silver dollar have not been realized" (Woolley and Peters n.d.). Though he stopped short of suggesting that the Treasury coin silver on demand.

\section{Developing Political Support}

Successful passage of the Republican economic agenda depended on Harrison's ability to work with, or manipulate, the incoming $51^{\text {st }}$ Congress between late 1889 and early 1891 . This would not be easy. Some issues badly divided Republicans or endangered their re-election. And much legislation depended on party-line votes, meaning that defections on either side could either jeopardize or guarantee passage. Congressional Republicans held a slim majority; reversals of just three seats in the House or one in the Senate would break it. All of this required Harrison to actively create and maintain allies on Capitol Hill, and to foster the good-will and support of the American public for the Republican program.

At this Harrison both excelled and failed. He could magnetize a crowd with his speeches, which he gave often. And unlike his predecessor, he regularly consulted with Congress on his major addresses and annual messages to Congress, which he used to signal paths forward. He also invited Congressional leaders to special White House dinners and receptions, during which Harrison discussed legislative design and strategy with them. And although Harrison used only one-tenth the vetoes of Grover Cleveland, he used the threat of veto adroitly to shape policy to forge Republican unity, or to match his rare policy preference. Indeed, he later wrote that the veto threat was his most effective legislative tool (Socolofsky and Spetter 1987, 48). And yet, Harrison generally refused to use patronage as a means to pressure Congress for legislation he favored (ibid., 43).

Unfortunately, one-on-one, Harrison was vastly different than his magnetic public persona. While he was warm to family and friends, to most others he was alternately abrupt and rude, or silent and dismissive. Harrison could "say NO so loud and sharp that it will make your teeth rattle" observed one reporter (Sievers 1968 , 49). A senator recalled "... whenever he did anything for me, it was done so ungraciously that the concession tended to anger rather than please” (Socolofsky and Spetter 1987, 33). Ohio's Governor simply 
called him "grouchy" (Foraker 1916, 425). Others described Harrison as lacking personal warmth. "It's like talking to a hitching post" joked one Senator (Sievers 1968, 43). "He is narrow, unresponsive, and oh, so cold!" complained a reporter (ibid.). Thus, Harrison soon earned the nickname of "iceberg" and his White House as an "icebox". It did not help that Harrison "believed that handshaking was both undignified and unhealthy" and avoided it by awkwardly withholding his right hand or by wearing kid gloves (Moore 2006; Ellis 2008). ${ }^{34}$ Visitors to the White House were warned "Don't feel insulted by anything he may do or say...it is only his way" (Morgan 1969, 229). Many in his party came to personally hate him. In spring 1891, a freshman senator observed “...no one cares anything for him personally" (Sievers 1968, 199). In particular, Harrison regularly infuriated the Republican House Speaker, who routinely excoriated him in exchange. Their "dislike was cordial and undisguised" observed one Congressman (Socolofsky and Spetter 1987, 80).

\section{0 and the Billion Dollar Congress}

Nevertheless, from December 1889 until March 1891, the $51^{\text {st }}$ Congress would support much of Harrison's proposed economic program. At first, House Democrats attempted to rebel, using parliamentary tactics to avoid quorums and obstruct legislation. But newly appointed House Speaker, Thomas Reed (R-ME), who served simultaneously as Chairman of the Rules Committee, and was himself a master parliamentarian, forced through changes in the House rules to end these practices. Together, President Harrison and "Czar Reed" proceeded to pass plank after plank of the Republican Party platform. In fact, the list of legislative accomplishments made by Harrison and the 51st Congress is impressive, one of the most productive governments in US history (Socolofsky and Spetter 1987, 47; HSUS 2006). ${ }^{35}$

One of their earliest, and perhaps greatest accomplishments, at least from Harrison's perspective, was the Dependent and Disability Pension Act, signed in late June 1890. It was the first major federal welfare program in US history. Strongly backed by Harrison, it provided federal pensions to qualified veterans, as well as their widows, minor children, and dependent parents. Within ten years, the program was consuming 30 percent of federal spending to provide support for almost 1 million Union Army veterans and their families with monthly payments of $\$ 6-\$ 100$ (in a period when monthly wages averaged around $\$ 30$ ), depending on the case (Costa 1998; Blanck and Millender 2000, 4). ${ }^{36}$ This equated to coverage for over 20 percent of all white males over the age of fifty-five (Costa 1998). Coverage was so broad that it has been described by experts as the most expensive and generous state pension program "ever passed by any legislative body in the world," eventually serving as a basis for modern Social Security created in 1935 (Skocpol 1993).

Next came the Sherman Anti-Trust Act of 1890, the first federal law to successfully regulate large corporations (Kovacic 2010, 39-42). ${ }^{37}$ Harrison had never held strong views about monopolies, but he did support the Republican party's survival. For decades, complaints about monopoly abuses, especially by railroads, had deluged Congress. In early 1887, a bipartisan Congress had passed the Interstate Commerce Act to regulate railroads, but it did not cover other monopolies; indeed, it failed even to govern the rails (A. Hoogenboom and O. Hoogenboom 1976). So, in response to broad public anger, Harrison and the Republicans backed the Sherman Anti-Trust Act. For although they may not have cared much about monopolies, the Republican party adored trade protectionism. And they likely recognized that anti-trust law was a politically necessary compromise to guarantee passage of the McKinley tariffs, which were expected to reward and further empower anti-competitive monopolies (DiLorenzo 1990, 1-32; Dickson and Wells 2001, 3-14; see also Peritz 2001; Stigler 1985, 1-12; Newman 2018, 257-275). Thus, the Sherman Anti-Trust Act passed the House and Senate in a rare and overwhelming bipartisan effort that spring, Harrison then signed it in early July. It seemed to be an historic step in the fight against inefficient monopolies. Ideally, it outlawed "every contract, combination in the form of trust or otherwise, or conspiracy in restraint of trade or commerce among the several states or with foreign nations." (The Sherman Antitrust Act 1890). But it was too vaguely worded and, during the 1890s, too poorly staffed or funded, to launch many investigations. Nor did Harrison prioritize its enforcement. His Attorney General initiated only seven anti-trust cases, and won just one of them while in still office. Even then, the damages were limited to only $\$ 5000$ (around \$150,000 in 2019 dollars) per conviction (Hauberg et al. 1990, 8). ${ }^{38}$

\section{The Rise of the McKinley Tariff of 1890}

Trade policy was the major legislative battle of the $51^{\text {st }}$ Congress and the focal point of its entire first session (See C. Johnson 2018; Irwin 2017; Palen 2016). Economic nationalism and protectionist sentiment had 
swelled to fever pitch amongst top Republicans in Congress and within the Harrison administration (Palen 2016). Two years earlier, President Cleveland had whipped the country into a frenzy with his broadside attacks against high protectionist tariffs. This transformed trade into the signature issue in the 1888 elections. To Republicans, their victories in those elections appeared to deliver a ringing endorsement for higher tariffs, or at least a stinging rejection of downward revisions. So, despite his own flexible history on trade policy, Harrison was willing to negotiate away much legislation he did favor, for the sake of party unity and a Republican "win" on tariffs. The problem was that almost every tariff had a different set of friends and enemies. Hence, much other legislation passed, or abandoned, in 1890, was done to engineer votes for higher tariffs.

In early March 1890, Republicans initiated the tariff fight with days of Congressional hearings in order to generate public support. Meanwhile, representatives of the sugar, textiles, and metals industries were quietly invited to submit their own tariff schedules. Congressman William McKinley (R-OH), an arch-protectionist, managed the process. He submitted a comprehensive tariff bill in April 1890. Its goal, he proudly declared, was "to increase production here, diversify our productive enterprises... and increase the demand for American workmen. What American can oppose these worthy and patriotic objects?" (McKinley 1890). In a symbolic nod to Western farmers, new duties were imposed on imports of wheat, corn, and barley, despite the fact that foreigners shipped little of these into the United States. Duties on sugar were cut, and domestic sugar subsidies were provided, to relieve the fiscal surpluses and to help sugar refineries in the Northeast. The new sugar provisions also helped consumers of all sorts of sweetened and canned goods. Duties on foreign tinplate, the basic input for the American canning industry, were jacked up in order to stimulate domestic production. Other protectionist plums and special inducements permeated the bill. It passed the House on a nearly strict party-line vote in late May.

However, when McKinley's trade bill reached the Senate, it was held hostage by opponents of pending legislation on black suffrage, public education, and silver. Harrison, who had come to support black suffrage and public education, now faced a dilemma. In the South, blacks were increasingly prevented from voting by various means, both legal and criminal. To counter Southern attempts to reverse the 15th Amendment, the Federal Elections Bill of 1890 established federal supervision of congressional elections (Calhoun 2006). Harrison was a passionate supporter. "When and under what conditions is the black man to have a free ballot?" he demanded, "When is he in fact to have those full civil rights which have so long been his in law?" (Woolley and Peters n.d.). Hence, while the Senate debated the McKinley tariffs, Harrison also launched an aggressive crusade to pass the Elections bill. It proved a measure too far. Harrison had campaigned for, and won, the presidency mostly on trade protectionism. And much of the legislative session was craft so as to engineer a major legislative victory on tariffs. Now, Harrison's sudden push for the Elections Bill threatened to derail it. Not only did white Southerners oppose black suffrage, but American industry in the North, an increasingly powerful supporter of the Republican Party, was beginning to view African-Americans less as "ex-slaves" and more as cheap labor, and therefore sought to decrease their power at the voting booth. Despite great personal effort, Harrison could not get both the Federal Elections Bill and the McKinley Tariff. The former fell to the priority of the latter.

Another measure, the Blair Education Bill, sought to use federal aid for education in the South, both to increase the economic opportunities for Blacks and to degrade the ability of literacy tests to prevent them from registering. Harrison had actually long supported public aid for education, especially for the Black community. But he abandoned the Blair bill to soothe his party's fears about cost, constitutionality, and Federal control over local education, as well to forge bipartisan support for tariffs. Harrison instead settled for the Second Morrill Act (signed August 1890). It feebly attempted to eliminate racial discrimination in college admissions policies. More effectively, it established Federal funding to support seventeen new land-grant colleges for African Americans in the Southern states. ${ }^{39}$

Harrison believed that these delays in black suffrage and education were merely temporary political expedients, and that African-American rights would be taken up again in the next Congress. He was badly mistaken. The 1890 election and education bills would prove to be the last major efforts by any President or Congress to aid African Americans in the South until the 1960s.

\section{Silver Purchase Act of 1890}

America's dedication to gold was Harrison's next sacrifice for party unity and protectionism. In a major enlargement of the Union, during 1889-1890, he supported legislation admitting six new states in the West, 
breaking a political logjam on new admissions that had existed for over thirteen years. ${ }^{40}$ The newly admitted states delivered a block of twelve senators and seven House members, all solid Republicans, further strengthening the party's majorities in Congress. These new Republican states backed silver coinage because they needed credit expansion for local investment and possessed vocal silver mining interests. And they were willing to trade their support for protectionism for it. A Western Republican put it bluntly

"In all Nevada there is neither a spindle nor a loom, and the prairies of the Dakotas stretch for hundreds of miles unlit by furnace fire. How can Massachusetts expect that the people of the Northwest will continue to vote for a high protective parent tariff to sustain New England factories when both political parties in Massachusetts openly avow hostility to the great exporting industries of the Northwest?" (Frieden 1997, 387).

Until Harrison, all post-bellum Presidents had argued against silver coinage and for progress towards the gold standard. President Grant (1869-1877) had supported pro-gold legislation in Congress that eliminated silver as legal tender. Private citizens could still use silver coins, but the US Treasury might not accept them, nor would the US Mint coin silver upon demand. President Hayes (1877-1881) then reduced the supply of inflated paper currency, achieving convertibility between printed greenbacks and gold in January 1879. Nevertheless, pro-silver forces passed the Bland-Allison Act over Hayes' veto; it required to the US Treasury to purchase and coin \$2-4 million worth of domestic silver bullion annually. Hayes used his power to ensure that only the minimum amount was minted. Neither Presidents Garfield (1881) nor Arthur (1881-1885) took strong stands on the currency issue, but no major legislation was passed under them. Then, President Cleveland (1885-1889) had faltered. He viewed currency and debt like any other government function: a potential source of corruption or largess. He therefore agreed with his "hard money" predecessors, and initially tried to keep US finances run on the most efficient and least inflationary manner, which meant gold. But he failed to repeal Bland-Allison when he had the chance in 1885-1886. Thus pro-silver interests felt emboldened to increase their attacks on gold.

Harrison now flagrantly betrayed the faith. He claimed to stand for a strong, reliable currency. But he had always skirted the silver issue for the sake of party unity. The new Republican silver-producing states and the tariff battle only furthered Harrison's resolve to "do something for silver" and thereby ensure harmony within the party, many of whom now supported bimetallism (Dunn 1922, 36). Towards the end of Harrison's first year in office, his Treasury Secretary floated a plan in which the Federal government would use government bonds to purchase all silver on America's domestic market. In his first annual message to Congress, Harrison referenced this plan and came out in support of bimetallism.

This opened the floodgates to pro-silver legislation in Congress. Harrison coaxed and cajoled the Senate for a compromise, while "Czar Reed" held the party together in the Republican-dominated House. During late spring and early summer 1890, Harrison hosted a number of White House meetings with key Senators and "threw his entire weight behind" a new Silver Purchase Act, along the lines his administration had proposed. The Senate finally passed it during mid-July. Harrison signed it days later. It did not allow the free coinage of silver, nor a de facto shift towards a silver standard, as demanded by many silverites. But it did require the Treasury to purchase 4.5 million ounces of silver every month, or nearly the entire US silver output (Timberlake 1993; Friedman and Schwartz 1963). ${ }^{41}$ In future months, Harrison largely ignored calls to defend the goldstandard. A senior Republican Senator later claimed "The silence of the president on the matter gave rise to an apprehension that if a free [silver] coinage bill should pass both Houses he would not feel at liberty to veto it" (Sherman 1895, 1070). ${ }^{42}$

It is not clear that Harrison's generosity towards silver was necessary. For while support for silver coinage was rising in both parties, only one-third of state-level Republican party platforms then supported it, while just under two-thirds in the Democratic party did (Bensel 2000, 136). And while no party explicitly endorsed the gold standard, the House reliably voted against silver. It was Senators from the newly admitted silver states who were the major obstacle to gold. They wanted nothing less than the free coinage of silver, hence the end of the gold standard. But only around 20 percent of the Senate was from silver-producing states. Therefore Harrison might have used his veto power, and perhaps patronage, to win their support for tariffs, pensions, etc. But Harrison instead prioritized Republican party unity. 


\section{The Passage of the McKinley Tariff of 1890}

With silver taken care of, Harrison and Congress returned to trade protection. The Senate passed the McKinley tariff bill in early September on a strict party-line vote. It then took over two weeks of torturous negotiations to transform the Senate and House versions into a compromise bill for President Harrison's signature.

In the meantime, however, a financial panic was brewing. Harrison may have forged Republican party unity and won impressive legislative victories, but his economic legislation was sending the U.S. Treasury disastrously into imbalance. Throughout summer, imports flooded into the country as Americans stocked up on foreign goods in anticipation of steep tariff hikes. The result was a sudden and severe trade deficit, hence a drawdown on US gold reserves. The massive Federal spending anticipated by the Pensions Act, sugar subsidies, naval construction, and other measures, as well as the promise of pro-silver legislation, combined to pose further threats to US gold supplies. Meanwhile the British had hiked their interest rates, attracting investment out of the US and into London. "The situation, therefore, is serious and embarrassing..." fretted the New York Times, which blamed the brewing crisis partly on "the foolish and wicked legislation of Congress and from the policy which the Treasury... has chosen to follow from purely partisan and unjustifiable motives." ${ }^{43}$

In mid-September 1890, with demand for scarce money and credit rising due to harvest season, the financial sector began to panic. Harrison, then on vacation, immediately wired the Treasury department to increase the money supply by making early interest payments on US bonds, buying bonds, and accelerating pension payouts. He also sent senior Treasury officials to consult with, and reassure, bankers in New York City on Federal action. On their combined advice, Harrison continued to increase bond sales as needed to expand the money supply and prevent a bankers' panic.

Meanwhile, Congress continued its negotiations on a final trade bill, which Harrison signed in early October 1890. It was the first wholesale reform of US trade policy since the Civil War. The McKinley Tariff of 1890 raised duties on almost fifty pages of listed imports to an average of 49.5 percent, the highest duties and on the most goods since the American Revolution. Within the bill, Harrison also won for the President unprecedented authority to manage America's international trade. The President was given authority to hold trade conventions, to independently negotiate reciprocity agreements (i.e., to offer lower duties on foreign imports in return for lower rates on American exports), and to create the federal administrative apparatus necessary to oversee the new tariff regulations. During 1891-1892, Harrison used this new authority to negotiate trade agreements to increase US exports into Brazil, the UK, Germany, France, and Austria-Hungary and a handful of other countries. These agreements were short-lived, however; abrogated by the 1894 Wilson-Gorman Tariff.

The new McKinley tariffs were drastic, widespread, and most took effect immediately. Total imports dropped over 4 percent in October alone, then another 11 percent in November; by December, imports were over 21 percent off their summer high (NBER n.d.). ${ }^{44}$ Some of this falloff in trade was seasonal, or due to purchases shifted earlier in the year to get ahead of the tariffs. But much of it was enduring. For example, imports of iron and steel fell immediately, dropping by half within a year (C. Johnson 2018, 123). Imports of other industrial materials also dropped precipitously by 1891: lead ( 80 percent), zinc (40 percent), sulfur (30 percent); while crude foodstuffs and finished manufactured goods suffered only slightly lesser declines (20 percent and 5 percent respectively) (HSUS 2006). ${ }^{45}$ And since some US products combined tariffed imports with domestic inputs, the costs of these goods increased as well. The tariffs were so pervasive, complained Democrats, that " $[\mathrm{t}]$ he McKinley bill is with us always, at the table, at the bedside, in the kitchen, in the barn, in the churches and to the cemetery" (Bolt 1970, 50). Senior Republican leader James Blaine warned that "such movements as this for protection will attack the Republican Party only into speedy retirement" (Irwin 2017, 269). Even the author of the tariff bill, William McKinley, later admitted "that some [tariffs] were too high" (Olcott 1916, 127).

Subsequent analysis of the McKinley Tariffs has been harsh (Irwin 2017; C. Johnson 2018). The new tariffs increased costs for nearly all American consumers, albeit marginally, while increasing the wealth of a much smaller number of US producers. Higher tariffs shrank trade, likely shaving half a percentage point off of US GDP growth (Irwin 2017, 284). Nor does the tariff appear to have provided critical protection for infant industries (See Pursell 1962, 267-284). "[W]ould not all this growth have taken place in any case?" asked one economic analysis, years later (Taussig 1915, 153). ${ }^{46}$ Some US industrial jobs and wages may have been protected, or at least the data suggest that they did not suffer much. But the overall costs imposed by the 
McKinley Tariff on American society, in the form of higher prices, were likely not worth the net benefits, if any, concentrated on relatively few producers (Irwin 2000, 335-361). Rather, the tariffs mostly served to transfer wealth out of agriculture and the South, into industry and the North and West, and to help fund the generous Pension Act for Union Army veterans (Skocpol 1992). And since America was by now such a huge market for foreign exports, the new tariffs helped trigger economic recessions in Canada, Great Britain, Switzerland, Japan, Chile and other major exporters to the United States (Maddison Project Database 2018; Birnie 2006; Berend 2012; Easterbrook and Aitken 1956; Tolliday 2001).

\section{Midterm Elections}

A month later, the 1890 midterm elections delivered a national referendum on Harrison and the Republicans. Conservatives denounced the unprecedented expenditures of "the Billion-Dollar Congress", to which Republicans ineffectively responded "Yes, but this is a billion-dollar country." (Grant 2011, 288)Other critics lambasted the new tariffs, silver, or failed civil service reform. In the Midwest, frustrated Populist campaigners, who sought to defend poor farm and industrial labor against monopolies and industrial capitalism, exhorted farmers to "raise less corn and more hell" (Cochrane 1993, 311). That November, angry voters swept Republicans out of office. Democrats took 235 seats in the House, a two-to-one majority! Third parties and independents took another 10 seats. Republicans were left with a tiny minority of just 86 seats (around 26 percent) in the House. State and local issues determined the make-up of the state legislatures, which appointed men to the US Senate (Bansel 2000; McKnight and Unger 2017) ${ }^{47}$ Hence, the Republicans retained a slim Senate majority (53 percent). But several of these surviving Republican Senators had voted against the McKinley Tariff bill, and McKinley himself lost re-election to the House. As for President Harrison, he blamed the 1890 rout on apathy; Republican voters were not angry, he explained, but "lacked interest and simply stayed away" (Sievers 1968, 181). ${ }^{48}$

The week following the elections, Britain's enormous Baring Bank nearly failed, threatening a global economic crisis (Michener and Weidenmier 2008, 462-500). "The whole human race seemed to be in collapse: revolution and financial bankruptcy in Portugal and Brazil, the coup d'etat in Chile, war in Central American, a financial and commercial crisis in Argentina, a building crisis in Italy" recalled the new Journal of Political Economy (Wirth 1893, 234). Fast action by the Bank of England saved Baring, but only by diverting European lending and investment away from the US and into the London money centers. As money and credit rapidly contracted in the US, the financial sector there began to panic. To increase the US money supply, Harrison again ordered the Treasury department to buy bonds and increase pensions disbursements. The President and his Treasury Security also pressured bankers to increase lending and credit from their reserve funds. Finally, Harrison worked with a special Senate committee to legislate increases in silver and paper currency. Confidence was quickly restored and a crisis avoided.

Meanwhile, with the clock now ticking on their majorities in Congress, Republicans huddled with Harrison to put together a final legislative agenda. On its last day, March 3, 1891, the lame-duck $51^{\text {st }}$ Congress passed a flurry of Republican bills supported by Harrison. The Land Revision Act of 1891 reformed Federal lands policy to prevent the abuse, fraud, and exploitation that had run rampant under older legislation. The Forest Reserve Act of 1891 gave the President authority to conserve natural resources by withholding public lands from private development, thereby creating the legal basis for the modern national forest system. Harrison immediately used the Act to create what is now Yellowstone Park (Graham 2015). ${ }^{49}$ The Immigration Act of 1891 set up a new executive superintendent with direct control over immigration, and established harsh guidelines against the admittance of the poor or migrants with histories of criminal behavior, "moral turpitude", or evidence of "loathsome" or "contagious" diseases. Harrison urgently requested, and Congress authorized, the construction of new battleships and other measures to continue the modernization of the US Navy begun under President Chester Arthur (1881-1885). Harrison also sought to enlarge and modernize the US merchant marine fleet. To this end, the Ocean Mail Act of 1891 subsidized US steamships to carry mail and established a series of trade-routes that remained in use for decades. Harrison supported national infrastructure with a million-dollar Federal improvement program of the Mississippi River. In order to gain reciprocal copyrights protection abroad for US authors, the International Copyright Act of 1891 created the first protections for foreign works in the United States. The Judiciary Act of 1891 created the US Circuit Court of Appeals, thereby increasing the efficiency of the Federal courts system. And to resolve trade disputes with Europe, Harrison got Congress to create the first federal standards for meat inspection of exports. ${ }^{50}$ 
After an exhausting and victorious legislative session, Harrison departed for a five-week transcontinental tour during spring 1891. He visited 21 states and two territories across the South and West, delivering over 140 speeches touting his administration's, and the nation's, accomplishments, as well as national unity, patriotism, and the flag (Dozer 1948, 48-77). Harrison traveled for free on the Pennsylvania Railroad in five luxury cars, provided specially for him, "of the latest build, vestibuled, lighted by electricity, and furnished with the newest appliances of all kinds". ${ }^{1}$ The New York Times questioned whether "[t]o the distressed farmer...this glittering, red and gold, and steel-blue parade, at no cost to the President, may seem like a mockery, as it certainly will to men who are being told that the panacea for their ills will be found in the McKinley bill, if they can live long enough to get over its first oppressive effects. ${ }^{.52}$ But generally, the trip was a success, with large crowds turning out to greet their president.

\section{The Revenge of Harrison's Economic Agenda: The Recession of July 1890 to May 1891}

Harrison's economic agenda likely exacerbated a shallow economic recession which had begun during July 1890. Gold flight, bank failures, and nervous investors caused the stock market to drop 18 percent between May and December of 1890 . Worse yet, the US Treasury began paying some debts in paper rather than gold or gold certificates, further alarming investors (Freidman and Schwartz 1963, 106). Industrial production soon followed downwards, falling over 19 percent between roughly October 1890 through April 1891. For the year 1890 , the economy shrank, though only slightly, around 0.6 percent, while deflation continued at -1.8 percent (Maddison Project Database 2018) ${ }^{53}$ Harrison then threw fuel on the financial fire, in April 1891. Not yet six months after passing the Silver Purchase Act, Harrison further emboldened free silver proponents. He wrote to a major silver conference that he had "always believed, and do more now than ever believe, in bimetallism, and favor the fullest use of silver in connection with our currency..." (Sievers 1968, 59).

The US was temporarily saved from major economic troubles by a freak weather event. European crops suffered a massive failure thanks to months of drought followed by frost, heavy snows, strong winds, and deep freezes during the first months of 1891. In some parts of Europe, "the winter came on so suddenly that the fields could not be well prepared before heavy snowfalls covered them up". ${ }^{54}$ The cold persisted deep into April, "Every morning the thermometer stands close to freezing point" reported The Economist. ${ }^{55}$ Harsh winter weather also snarled European transportation networks. As a result, that spring and summer, food prices soared across Western and Central Europe, while Russia declined into famine (Alfani and Gráda 2017). Meanwhile US farmers enjoyed record crop yields. US food exports boomed, temporarily reversing the outflows of gold and boosting the US money supply. Domestic demand for farm equipment, grain storage, and transportation soon followed. Thus, between May 1891 and May 1892, American agriculture and industry enjoyed a temporary comeback.

\section{Homestead Strike of 1892}

Meanwhile, the ongoing conflict between industry and labor entered a new stage. Strikes erupted around the country during the Harrison administration, hitting a record of 1,897 strikes in 1890 with some 393,000 workers participating, or around 4.2 percent of the American industrial workforce (HSUS 2006) ${ }^{56}$ The following year was only slightly better (1,786 strikes involving 300,000 workers, or around 3.6 percent of the workforce). Membership in labor unions, which had been dropping since its frenzied peak in 1886, resumed its upward climb (ibid.). ${ }^{57}$ One problem was that since 1888, the average wages for unskilled labor had stayed flat, while urban-crowding and tariffs threatened to drive the prices of food, housing, and transportation in the cities, ever higher (ibid.). ${ }^{58}$ This was especially ominous as the 1890 census revealed that, for the first time, over onethird of Americans now lived in cities; up from one-quarter just two decades earlier (ibid.). ${ }^{59}$ Also, for years, manufacturers had replaced men with machines where possible, cheap immigrant labor was imported where not; all while demanding ever longer work hours. Unions angrily protested. "[T]he wealth of the country becomes centralized, its power increases, and the laboring classes are more or less impoverished" complained the Amalgamated Association of Iron and Steel Workers (Demarest and Weingartner 1992, 17). Something had to give.

Tensions climaxed in early July 1892, when an industrial lockout and strike at the Carnegie Steel plant in Homestead, Pennsylvania turned into a massacre (Krause 1992; Wolff 1965; Demarest and Weingartner 1992). Striking members of the metal workers union and hundreds of private Pinkerton security agents battled it out with rifles and small cannon, while bystanders took part with stones and clubs. "[T]he town is red with 
blood" reported the St Louis Dispatch ${ }^{60}$ Seven men died and many others were wounded. The Governor of Pennsylvania mobilized the state militia to escort "scab" workers in and restart the plant. A Russian-born anarchist, aided by a fellow activist, attempted to assassinate a senior Carnegie official in his Pittsburgh office. This was no ordinary strike, but "a momentous battle between the nation's most powerful steelmen...and the workers, led by the country's largest trade union" over automation, immigrant labor, and corporate power (Krause 1992, 3). It was organized warfare. Private armies of industry and workers fighting it out in the streets. It was unlike anything the nation had seen before.

Harrison, however, did little. Vacationing in upstate New York, he added to a scheduled speech a few lines about "Obedience to law; deference to public authority", and privately pressured Carnegie to negotiate. But otherwise he took no action. Instead, state militia were called in. They seized the factory and arrested hundreds of strikers. The local union then descended into bankruptcy as it struggled to defend them. Scabs got the Carnegie factory running again and, within a few months, the remaining strikers gave up. And rather than address worker grievances, the following year, the Harrison administration successfully applied the new Sherman Anti-Trust Act against strikers in New Orleans and in Georgia (Blindell v. Hagan; US v. Workingmen's Amalgamated Council).

\section{The Cholera Scare of 1892}

To be fair, Harrison was by now increasingly distracted by personal tragedy. In late December 1891, his wife contracted tuberculosis. For the next ten months, she battled the disease, and mental depression, until she died. Harrison was devoted to his wife, and lightened his schedule during mid-1892, especially his presidential campaign, in order to care for her. "Politics and business have been crowding the day and night, and with the anxiety by your mother, makes life just now a burden and ambition a delusion" he wrote to his daughter (Sievers 1968, 241-242).

Yet, to his credit, in September 1892, Harrison rushed to Washington D.C. to personally coordinate the federal response to a cholera scare (Markel 1997). Several ships bearing Jewish migrants from Russia threatened to bring the disease into New York. Over a hundred passengers had contracted it via a deadly outbreak in Hamburg, Germany, where newspapers reported that "So great is the terror caused by the cholera...Business is prostrate, and shipping is going to other ports". ${ }^{61}$ A cholera epidemic in New York City, striking at the financial, commercial, and transportation hub of the nation, could have been an economic disaster. "READY FOR THE PLAGUE" warned the New York Sun. ${ }^{62}$ Harrison endorsed a three-week quarantine on immigration, despite questions about his authority to do so, thereby averting a potential pandemic. He then worked swiftly with Congress to pass legislation to create a national system of quarantines to defend against the spread of pandemic disease (The National Quarantine Act of 1893).

On the other hand, few legislative options remained for Harrison to advance his more partisan economic goals. When the $52^{\text {nd }}$ Congress returned to its full session in early January 1892 , the House was dominated by Democrats, and much of the Republican platform had already been enacted. Thus, Harrison achieved far less after spring 1891 than during the first half of his administration. He was not totally incapacitated. For some significant legislation was passed during this time. For example, Harrison signed the bipartisan Geary Act (May 1892) meant to aid American workers by extending the 1882 Chinese Exclusion Act for an additional 10 years, and requiring Chinese immigrants to carry identification papers. He helped Congress to enact an eight-hour workday for federal blue-collar workers (August 1892) ${ }^{63} \mathrm{He}$ signed off on new Federal mandates for safety requirements on railway companies (March 1893). Nevertheless, Harrison and his Republican allies spent much of their time defending against attempts by House Democrats to rescind the work of the $51^{\text {st }}$ Congress. Hence, during his last two years in office, Harrison switched his focus to foreign policy, where he achieved relatively little.

\section{The Economy in 1892}

In spring 1892, the economy began a gradual descent that lasted for the remainder of Harrison's presidency (NBER n.d.). ${ }^{64}$ The stock market was first to show signs of weakness. It crested in March 1892, and then slowly trended downwards for the next sixteen months, a decline of around 60 percent. Agriculture prices followed. After peaking at $\$ 1.08$ per bushel in April 1892, wheat fell almost every month for the remainder of Harrison's presidency, hitting 74 cents the month he left office, a decline of over 30 percent (ibid.). ${ }^{65}$ By 
summer, it was industry's turn to contract; though here, the pullback was smaller, only around 2-3 percent by the end of Harrison's term.

But it was the gold-silver situation that most disturbed markets. Encouraged by Harrison's willingness to yield on currency issues, in early July 1892, the Senate passed a bill allowing free coinage of silver, spooking investors. It died in the House, but the damage was already done. Banks and the US Treasury alike began to hoard gold. For nearly six years, the use of silver in the United States had been on the increase, and a dollar devaluation now seemed like only a matter of time. "[T]he general opinion seems to be that Harrison's election will bring... London selling" advised the Wall Street Journal. ${ }^{66}$ For, when combined with his federal spending that ate dangerously into the budget surplus, Harrison's amity towards silver put America's finances on shaky ground.

Harrison would go on to lose his re-election bid in November 1892. He won just 43 percent of the popular vote, which translated into just one-third of the electoral college. While voter suppression, trade, silver, and labor issues all played a role, Harrison's campaign was most handicapped by his own absence from it, due to his wife's illness and death, and by his single-minded approach towards federal appointments. For Harrison had lost the popular vote four years earlier, and partly owed his 1888 election to a handful of machine bosses, donors, and droves of energetic and scheming supporters across the Republican Party. After his victory, they had eagerly awaited their spoils. But rather than enthusiastically reward their efforts, Harrison had kept silent about senior appointments for months, and then he generally failed to hand out cabinet or patronage slots according to the wishes of his high-ranking Republican supporters. Harrison thereby frustrated Republican bosses, and alienated powerful political allies. Now, four years later, the Republican political machines and party activists felt little motivation to get out the vote for Harrison. "[H]is manner of treating people who came to him had filled the country with bitter and powerful enemies," recalled an ally, "while his friends were very few" (Depew 1923, 134-135). In fact, some attempted a "dump Harrison" movement, but failed to find a suitable challenger to replace him.

Regardless, the business press celebrated Harrison's downfall. "Financial circles feel new hope," declared the Commercial and Financial Chronicle ${ }^{67}$ For despite the threat of low-tariff Democrats taking power, bankers and businessmen celebrated "the name and character of ex-President Cleveland...for the sound financial views he holds and for the adoption of those views by the convention that nominated him." ${ }^{68}$ In fact, the Wall Street Journal observed that "so many good Republicans...voted for the Democratic party because they believe in Mr. Cleveland's modified protective ideas" ${ }^{\prime 9}$ Even the manufacturing community seemed relieved. "The [electoral] reaction against the present tariff, strangely enough, was not so pronounced in agricultural communities as in manufacturing localities" observed Iron Age, which assured readers that Cleveland would block any radical changes to protection. ${ }^{70}$ Instead, Cleveland would restore order to America's finances. If only the economy could hold out until spring "for the assurance which conservative legislation alone can impart". ${ }^{71}$

\section{The Great Depression of 1893-1897 Begins}

During the final months of Harrison's presidency, the economy spiraled down faster towards depression. Largely due to Harrison's fiscal and monetary policies, American deficits had mounted during the winter of 1892-1893, leading to a precipitous fall in the US Treasury's gold inventories (NBER n.d.). The healthy budget surplus of 111 million in 1888, had dropped to an anemic 2.3 million by 1892 and was rapidly headed into deficit (HSUS 2006). ${ }^{72}$ The business press regularly fretted about outflows of specie and the "real danger to our currency not remaining on a par with gold". ${ }^{73}$ A strong Christmas season suggested a strengthening economy during the final quarter of 1892, but the Rhode's Journal of Banking cautioned that "the present calm in the money market is simply the lull before the storm that is likely to break at any time...". ${ }^{74}$ By early 1893, businesses and individuals were reporting difficulty in acquiring gold, while the Commercial Bulletin headlines warned its readers of "The Impending Monetary Crisis". 75

During early 1893, conditions changed rapidly. Industrial production plunged 4.3 percent during just the first three months of the year. The stock market contracted sharply, by 8 percent, during the last five weeks of Harrison's presidency, and would not reach bottom until summer. In late February, the Philadelphia and Reading Railroad collapsed, sparking further selling on Wall Street. Harrison's Secretary of the Treasury considered a new bond issue to replenish federal gold stocks, but only as a last resort. For he "openly expressed [his] view...that his responsibility ended with the fourth of March [the end of Harrison's administration] and that he cared only to avert a catastrophe up to that date" (Steeples and Whitten 1998, 32). With scarce money or 
credit available for spring planting, and due to a recovery of European agriculture, that year's American farm situation would be amongst the worst of the decade. The price of wheat alone was down over 26 percent from when Harrison first took office. Overall, US real GDP per capita would shrink over 6.6 percent in 1893 . Hence the presidential transition of 1893 would prove one of the worst economic handoffs in American history.

Harrison seemed oblivious to the growing economic danger. In his final annual message to Congress, he praised "the general prosperity of the country", bragging that "[t]here has never been a time in our history when work was so abundant or when wages were as high..." (Woolley and Peters n.d.). And four years later, with the nation in the depths of economic turmoil, Harrison blamed the Depression not on his policies, but on lower tariffs passed by his successor. "Our manufacturers, left without adequate protection, have been successively and gradually closing up and putting out their fires", he argued. ${ }^{76}$ According to him, banks and businesses had then pulled back out of fear of cheap imports, while new fiscal policies failed to bring in enough revenues to fund the government and support the dollar. Of course, Harrison ignored the fact that it was his policies that had caused the fiscal deficits, credit contractions, and fears of currency devaluation in the first place.

\section{Conclusions}

Harrison's record on the economy is mixed. His vigorous responses to the two budding financial crises of 1890 were exemplary. In these actions, Harrison and his Treasury department behaved much like a modern Federal Reserve. They acted rapidly and forcefully to defend the US financial system. They did so by flooding markets with money and credit as much as was allowed by legislation at the time. The Harrison administration also coordinated with private bankers and Congress in serious, team effort to respond to the crises. And their swift, vigorous, comprehensive response helped to restore confidence and trust in the US financial system. Either of these two crises could have resulted in a major recession, perhaps even economic depression, had they been ignored or dealt with in a less aggressive manner by Harrison. The same can be said of Harrison's forceful reaction to the threat of cholera pandemic during summer 1892. Had any of these emergencies been treated with the traditional passiveness of $19^{\text {th }}$ century presidents, they might have wreaked devastating short-run effects on the economy. Thus, if we look at 1889-1893 in isolation, then Harrison did relatively well.

On the other hand, Harrison pursued a collection of policies that created the financial conditions for the Great Depression of 1893-1897. His combination of vast federal spending programs, revenue cuts, tariffs, and favor towards silver, together eroded trust in America's financial solvency and the US dollar. During the Gilded Age, the world's creditors expected to be paid in gold. Silver and paper currencies were considered of lesser worth (Timberlake 1993 \& Friedman et al. 1963). Therefore, when Harrison abruptly shifted the US off a trajectory towards the gold standard, and towards greater use of silver. Although he repeatedly insisted on maintaining the two metals" "equality in their commercial uses", investors feared devaluation and fled the US dollar when an economic slump hit in early 1893 (Woolley and Peters n.d.). This triggered one of the deepest, and longest, financial crises and economic depressions in US history.

Harrison appears to have followed this path because he prioritized Republican party unity, and aid to Republican interest groups, over strategic economic goals and cohesive policy. Otherwise, his politicaleconomic philosophy was a hodge-podge of inconsistent and changeable views. On trade and monetary policy, he discounted the costly trade-offs and dilemmas, and instead prioritized the political expediencies of the day (Sievers 1959, 275, 269). In fact, one scholar of the party observed in Harrison "a streak of blind partisanship which Harrison seldom exhibited outside the arena of politics. Not only did he defend party policies that had been out of fashion for a decade, but he did so with a conviction and logic that amazed his contemporaries" (Mayer 1964, 221). He opposed government welfare, yet backed the Pensions bill for US army veterans. He claimed to support a strong currency and national finances, yet he gutted the revenue streams necessary to provide them. He compromised America's dedication to gold because he wanted "to do something for silver", especially silver Republicans. His fraught personal relationships with Congressmen left him few opportunities to craft less blatantly partisan, and more economically constructive, legislation. And while he excelled at rallying and educating the public, he tended to do so only after legislation had been crafted and passed. Again, this surrendered a political tool that Harrison could have used to force through more sustainable economic policy. Writing just fourteen years later, in 1907, MIT economist Davis Rich Dewey laid the currency debacle of at Harrison's feet. "No incident in our national history more forcibly illustrates the lack of determined statesmanship" (Dewey 1907, 227). Thus, despite the fact that Benjamin Harrison was enormously talented, 
highly experienced, well-educated, deeply intelligent, and staunchly patriotic; he nevertheless created conditions which plunged the country into economic disaster.

Notes

1. Refers to Robert H. Bishop

2. "Miami University...could not have been more Presbyterian if founded by John Knox" the school's historian later wrote (Havighurst 1958, 46)

3. Harrison's graduation speech focused on explaining "The Poor of England", which he blamed on a shift away from private charity to government welfare.

4. His party selection may also have been driven by the stronger Presbyterian bent of the early Republican party, the greater chances for a young neophyte to move up in a new party versus the long established Democratic organization, and the unique networking opportunities provided by his new law partner, William Wallace (a Republican, son of a former Governor, and a candidate himself, with strong connections to the local party organization).

5. John Fremont, a former Governor and Senator from California, was the Republican party's first presidential candidate.

6. In 1860, Harrison had won election as Supreme Court Reporter of Indiana. "The post was not only a dignified one, but most lucrative" notes his biographer. And during the war, Harrison relied heavily on its income to support his family. But in August 1862, the Democrats forced his replacement with one of their own.

7. By 1872, Harrison had established his law firm and built up his family finances. Also, the governorship would allow him to stay home in Indianapolis, close to his family, friends, and church community. Hence he felt more comfortable running for this office, than for Congress after the war.

8. Harrison's rise in Indiana politics during the late 1870s was aided by the death of Republican governor and state machine boss Oliver P. Morton (1823 -1877). The two men had been friends and allies until 1872, when Harrison revealed in court the shady financial practices of several Republican party operatives, including Morton's brotherin-law. Thereafter, the powerful and tyrannical Morton considered Harrison disloyal and blocked his political progress. Harrison chose not to fight back and accepted years of near political exile.

9. James Blaine (R-ME), Republican party leader and US Senator, also had a strong showing as a shadow candidate.

10. Harrison was not the first presidential candidate to openly campaign, but the most systematic to date. During the 1880 presidential campaign, James A. Garfield lived close to a major rail line and therefore received delegates at his home, speaking to them from his front porch. Four years later, Senator James A. Blaine toured for six weeks to meet voters but then lost the election, an outcome Harrison was eager to avoid. As for Harrison, his "home in Indianapolis was so accessible that he could not discourage visitors, so he deliberately planned his campaign around many voter pilgrimages". (Socolofsky and Spetter. 1987, 11)

11. In 1888 , Cleveland received $5,534,488$ (48.6 percent) of the popular vote, Harrison won 5,443,892 (47.8 percent).; Table Eb149-153 Electoral and popular votes cast for President, by candidate: 1789-2000. HSUS.

12. Such a unusual event had occurred before only twice in American history (in 1824, John Quincy Adams who lost by 44,804 votes to Andrew Jackson; in 1876, Rutherford B. Hayes lost by 264,292 votes to Samuel J. Tilden) and would not occur again until the 2000 election (when George W. Bush who lost the popular vote by 543,816 votes to Al Gore).

13. Except for labor issues, which both Cleveland and Harrison dealt with similarly: a combination of neglect, sympathy for the workers, and support for the occasional use of force (or threat thereof) to quell striker violence and arrest strikers.

14. New York Times. 1896. (August 28)

15. Federal taxes on alcohol then constituted roughly 75 percent of internal federal revenues. Table Ea594-608 Federal government internal tax revenue, by source: 1863-1940. HSUS.

16. In particular, the 1834 Poor Laws under which "the charitable offering is snatched from the kind hand of the benevolent giver [e.g. the church and fellow citizens]..." and placed under control of a faceless, "soulless" government and funded with "compulsory" taxes which allowed employers to reap a "princely magnificence" while providing workers with only "a starving portion".

17. If American production were replaced by imports from Britain, then there should not be "less goods all around". Even if there were, a change in supply would not necessarily affect demand, at least not in the direction indicated 
by Harrison (e.g. even during the Gilded Age, many believed Say's Law which suggests that supply and demand should move together, not in opposing directions). Finally, if domestic prices increased so dramatically, then they would draw domestic producers back into the market.

18. For example, he supported President Chester Arthur's efforts to reduce tariffs in 1882-1883.

19. In his 1888 campaign, Harrison simplified his tariff logic to "[economic] competition with foreign countries, without adequate discriminating and favoring duties, means lower wages to our working people...free trade, means larger importations of foreign goods, and that means less work in America."

20. See for example his speech on the currency issue reported in Indianapolis News. 1876. (August 21).

21. Indianapolis News. 1876. (August 21)

22. Because silver obtained different dollar prices as coin versus bullion, restrictions or increases in silver coinage affected silver bullion's dollar value in gold. The same applied to printed paper greenbacks. Therefore it was contradictory to simultaneously favor a "sound currency" and greater usage of all three currencies.

23. Reid was also Harrison's running mate in the 1892 election campaign.

24. Harrison considered summoning legislators into special session to work on Republican legislation, but a few unresolved House seats made him worry that "any combination of accidents or misfortunes...[could] leave us without a Republican quorum at the special session" (Woolley and Peters n.d.).

25. In particular, a serious confrontation with Canada over seal fishing, and presiding over a long sought-after PanAmerican Conference to promote trade and investment.

26. Pittsburgh Daily Post. 1890. (July 25).

27. Table Ea894-903 Federal government employees, by government branch and location relative to the capital: $1816-1992$.

28. New York Herald. 1889. (March 17/18). (Quoted in Sievers 1968: 48)

29. Harrison was likely willfully convinced by his former classmate's view that his victory had been "with a graceful sweep over hill and dale along the lakes and from two oceans...It has come so honestly, and so full of good will toward all, so free from abuse that the campaign leaves no sting." (Sievers 1959, 427) However Calhoun disputes this interpretation, arguing that Quay's quotation was more a venting of frustration by a disappointed Quay than a sincere belief of Harrison, and that it may even be apocryphal. (Calhoun 2005; 2008)

30. Roosevelt complained that "the little gray man in the White House [looked on him] with cold and hesitating disapproval."

31. Senator James Blaine (R-ME), a.k.a. "the Plumed Knight", whom Harrison reluctantly appointed as Secretary of State. Thrice a candidate for President, a former Senate leader, ex-Secretary of State, and party boss, Blaine was an ambitious political diva throughout the Gilded Age. Yet by 1893, Blaine was in physical decline. For much of the Harrison administration, severe illness and the deaths of several of his children kept Blaine on the sidelines. On foreign policy, the two men agreed on much; at times, Harrison even took significant advice from Blaine. But Harrison served as his own Secretary of State for much of his administration.

32. NBER Macrohistory Database: IV. Prices. https://www.nber.org/databases/macrohistory/contents/chapter04.html

33. Table Cc1-2 Consumer price indexes, for all items: 1774-2003. (HSUS 2006); Municipal Bond Yields for New England, Percent, Quarterly, Not Seasonally Adjusted. (NBER n.d.)

34. Also, during the war, Harrison had developed a rash, perhaps scarlet fever, which rendered his skin extremely sensitive.

35. The first session alone lasted 303 days and has been compared with the ambitious 37 th "Civil War" Congress (under Lincoln), 1861-1863 and the 63rd "Progressive" Congress (under Wilson), 1913-1915. Over 2250 bills and resolutions were passed overall during the 51st Congress, more than any other Congress in the 19th century (and most of the 20th century).

36. Applicants had to prove that they had served in the Union Army for ninety days or more, had been honorably discharged, and that their disability was not due to addiction or sexual promiscuity (i.e. "vicious habits").

37. Also the first anti-trust law in the world.

38. True anti-trust action would await the early 1900s, and the presidencies of Theodore Roosevelt (1901-1909) and Howard Taft (1909-1913).

39. It guaranteed not just the survival of the existing land-grant colleges, created under the First Morrill Act (1862), but put them on a new trajectory towards becoming world-class universities.

40. North and South Dakota (November 1889), Montana (November 1889), Washington, (November 1889), Idaho (July 1890), and Wyoming (July 1890). Congress had passed, and the outgoing President Cleveland had signed, enabling legislation for the first four admissions in late February 1889; but their formal admission as states awaited 
Harrison's signatures seven months later. Cleveland and the Democrats had opposed these admissions, but gave way in light of victories by pro-statehood candidates in the 1888 elections. Also, Oklahoma was formally organized by Congress in the Oklahoma Organic Act (May 1890).

41. Payment would be in the form of Treasury certificates, which could be redeemed in silver or gold. There was also considerable leeway for the president, and market forces, to prevent rampant silver coinage.

42. Historian and biographer Charles Calhoun suggests that Sherman was being "disingenuous" here and that "Rather than grandstanding in a fashion that could paint the silverites into a corner, Harrison [had] worked behind the scenes [on monetary policy]". Calhoun therefore contends that "there was little doubt" that Harrison would veto silver free-coinage legislation. Personal correspondence with the author (July 2020).

43. New York Times. 1890. (September 12).

44. U.S. Total Imports 07/1866-10/1969. NBER Macro Database.

45. Table Db132-149 Metals-selected imports and exports: 1851-2000. HSUS; Table Ee446-457 Exports and imports of merchandise - crude and manufactured goods: 1821-1984. HSUS.

46. Confirmed in subsequent analysis by Irwin 2017

47. During the 1890s, state and local elections tended to focus on race and ethnicity, religion, and party loyalty.

48. After all, the 52nd Congress (1891-1893), though flush with Democrats, spent even more heavily and enthusiastically than the thoroughly Republican one it replaced.

49. President Grant had signed a law establishing Yellowstone in March 1872. But illegal hunting, poaching, vandalism, and reckless campfires beset it for years. Harrison's action expanded the park by 1.2 million acres and designated it as a national reserve, protected by the executive branch.

50. The 1891 legislation on meat inspections built upon a similar bill supported by Harrison the previous year.

51. New York Times. 1891. (April 14).

52. Ibid.

53. Real GDP per capita

54. The Economist. 1891. (April 25). Vol 49: 534.

55. Ibid.

56. Table Ba4954-4964 Work stoppages, workers involved, average duration, and person-days idle: 1881-1998. HSUS.

57. Table Ba4783-4791 Union membership: 1880-1999. HSUS.

58. Table Ba4218 Index of money wages for unskilled labor: 1774-1974. HSUS.

59. See also Table Aa716-775 Population, by race, sex, and urban-rural residence: 1880-1990. HSUS; Table Aa699715 Urban and rural territory - population, by size of place: 1790-1990. HSUS.

60. St. Louis Dispatch. (July 6). 1892. Quoted in Demarest and Weingartner 1992: 75

61. New York Sun. 1892. (August 26)

62. New York Sun. 1892. (August 27)

63. Congress had set an eight-hour day for federal workers back in 1868, but its results were disappointing. Federal wages were cut along with hours, private contractors were not covered, and private industry chose not to follow suit. Nor was the law well-enforced. The 1892 law extended the eight-hour workday to all federal workers, including contractors and subcontractors on public works projects. But again enforcement would prove lax.

64. Strangely, the NBER does not record this period as recessionary, or at least not until January 1893. US Business Cycle Expansions and Contractions. NBER Macro.

65. Wholesale Price of Wheat, Chicago, Six Markets for Chicago, IL (Cents per Bushel, Not Seasonally Adjusted), National Bureau of Economic Research. NBER Macro.

66. Wall Street Journal. 1892. (November 5).

67. Commercial and Financial Chronicle. 1892. (November 12).

68. Ibid.

69. Wall Street Journal. 1892. (November 10)

70. Iron Age. 1892. (November 17)

71. Commercial and Financial Chronicle. 1892. (November 12).

72. Table Ea584-587. Federal government finances-revenue, expenditure, and debt: 1789-1939. HSUS.

73. Wall Street Journal. 1892. (December 17). Also, after some encouraging discussions with foreign governments about bimetallism, the Harrison administration enthusiastically participated in a November/December 1892 international monetary conference to discuss a coordinated move towards silver. When the conference ended in failure, speculators who had bid up the price of silver in anticipation of an international agreement, now sold off. 
Wall Street pressured the Treasury Department for new bond sales so as to avert a panic and to defend federal gold inventories. This time, Harrison refused. He saw in the demand a financial scheme to drive up interest rates. The stock market remained unperturbed. However, these events increased the air of uncertainty and rising risk around the US currency. (See also Reit 1998; Sievers 1968, 252)

74. Rhode's Journal of Banking. 1893. (January) 20: 97.

75. Quoted in Wall Street Journal. 1893. (February 15).

76. Quoted in New York Times. 1896. (August 28)

77. Silver and paper came with greater risk and uncertainty due to the constantly changing price differences between coins (whose prices were fixed by legal statute) and bullion (whose prices floated, determined by the market).

78. For example in a letter to WW Slaughter (March 14 1885), Harrison wrote "a division of the white vote in the South furnishes the only possible solution...[such as] the tariff or some other financial question [to divide them]". Or on the currency, "Cleveland's silver letter has produced a wide and bitter break in his party in Congress... If we are left half a chance, we can beat them in 1886." (Sievers, 1959: 275, 269). 


\section{REFERENCES}

Alfani, Guido and Cormac Ó Gráda. 2017. Famine in European History. New York: Cambridge University Press.

Armbruster, Carl Joseph. 1958. Problems and Personalities of the Civil Service Reform in the Administration of Benjamin Harrison. Master's Thesis: Loyola University Chicago.

Bensel, Richard Franklin. 2000. The Political Economy of American Industrialization, 1877-1900. New York: Cambridge University Press.

Berend, T. Ivan. 2012. An Economic History of Nineteenth-Century Europe: Diversity and Industrialization. New York: Cambridge University Press.

Birnie, A. 2006. An Economic History of Europe 1760-1930. London: Routledge

Blanck, Peter David and Micahel Millender. 2000. Before Disability Civil Rights: Civil War Pensions and the Politics of Disability in America. 2000. Alabama Law Review 52(1)

Blindell v. Hagan, 54 F. 40 (1893)

Bolt, Robert. 1970. Donald Dickinson. Grand Rapids, MI: W.B. Eerdmans.

Bourdon, Jeffrey N. 2019. From Garfield to Harding: The Success of Midwestern Front Porch Campaigns. Kent, $\mathrm{OH}$ : The Kent State University Press

Calhoun, Charles W. 1993. Civil Religion and the Gilded Age Presidency: The Case of Benjamin Harrison. Presidential Studies Quarterly 23(4): 651-667.

Calhoun, Charles W. 2005. Benjamin Harrison: The 23rd President 1889-1893. New York, NY: Times Books.

Calhoun, Charles W. 2006. Conceiving a New Republic: The Republican Party and the Southern Question, 18691900. Lawrence, KS: University Press of Kansas.

Calhoun, Charles W. 2008. Minority Victory: Gilded Age Politics and the Front Porch Campaign of 1888. Lawrence, KS: University Press of Kansas.

Cochrane, Willard Wesley. 1993. The Development of American Agriculture a Historical Analysis. Second Edition. Minneapolis, MN: University of Minnesota Press.

Costa, Dora L. 1998. The Evolution of Retirement: An American Economic History, 1880-1990. Chicago, IL: University of Chicago Press.

Cullom, Shelby Moore. 1911. Fifty Years of Public Service. Chicago, IL: AC McClurg \& Co.

Demarest, David P. and Fannia Weingartner. 1992. "The River Ran Red": Homestead 1892. Pittsburgh: University of Pittsburgh Press.

Depew, Chauncey Mitchell. 1923. My Memories of Eighty Years. New York: Charles Scribner's Sons.

Dewey, Davis Rich. 1907. National Problems, 1885-1897, (Volume 24). New York: Harpers and Brothers Publishers.

Dickson, Peter R. and Philippa K. Wells. 2001. The Dubious Origins of the Sherman Antitrust Act: The Mouse that Roared. Journal of Public Policy \& Marketing 20(1)

DiLorenzo, Thomas J. 1990. The Origins of Antitrust. Regulation 26-34; Bittlingmayer, George. 1993. The Stock Market and Early Antitrust Enforcement. The Journal of Law \& Economics 36(1) 
Dozer, Donald Marquand. 1948. Benjamin Harrison and the Presidential Campaign of 1892. The American Historical Review 54(1).

Dunn, Arthur Wallace. 1922. From Harrison to Harding, A Personal Narrative of a Third of a Century 18881921, v. 1. New York: G.P. Putnam's Sons.

Easterbrook, William T. and Hugh G. J. Aitken. 1956. Canadian Economic History. Toronto: Macmillan Co. of Canada.

Ellis, Richard J. 2008. Presidential Travel: The Journey from George Washington to George W. Bush. Lawrence, KS: University Press of Kansas.

Foraker, Joseph B. 1916. Notes of a Busy Life. Vol 1. Second edition. Cincinnati: Stewart \& Kidd.

Frieden, Jeffry A. 1997. Monetary Populism in 19th Century America: An Open Economy Interpretation. Journal of Economic History 57(2).

Friedman, Milton, and Anna Jacobson Schwartz. 1963. A Monetary History of the United States, 1867-1960. Princeton, NJ: Princeton University Press.

Fuller, A. James. 2017. Oliver P. Morton and the Politics of the Civil War and Reconstruction. Kent, OH: The Kent State University Press.

Graham, Otis L. 2015. Presidents and the American Environment. Lawrence, KS: University Press of Kansas.

Grant, James. 2011. Mr. Speaker!: The Life and Times of Thomas B. Reed, The Man who Broke the Filibuster. New York: Simon \& Schuster.

Harrison, Benjamin. 1901. Views of an Ex-President. Indianapolis, IN: Bowen-Merrill Company.

Hauberg, Robert E. et. al (eds). 1999. Sentencing Guidelines in Antitrust: A Practitioner's Handbook. Chicago, IL: American Bar Association.

Havighurst, Walter. 1958. The Miami Years, 1809-1969. New York: Putnam.

Hayes, Rutherford B. 1888. Diary entry. (June 24)

Hedges, Charles. Speeches of Benjamin Harrison; a Complete Collection . N.Y.: Lovell, 1892.

Herring, George C. 2008. From Colony to Superpower: U.S. Foreign Relations Since 1776. New York: Oxford University Press.

Hoogenboom, Ari and Olive Hoogenboom. 1976. A History of the ICC. New York: W.W. Norton.

Historical Statistics of the United States, Millennial Edition. 2006. Edited by Susan B. Carter, Scott Sigmund Gartner, Michael R. Haines, Alan L. Olmstead, Richard Sutch, and Gavin Wright. New York: Cambridge University Press.

Huston, Alexander Botkin. 1909. Historical Sketch of Farmers' College. Cincinnati, OH: Students Association of Farmers' College.

Irwin, Douglas A. 2000. Did Late-Nineteenth-Century U.S. Tariffs Promote Infant Industries? Evidence from the Tinplate Industry. Journal of Economic History. 60(2).

Irwin, Douglas A. 2017. Clashing Over Commerce: A History of US Trade Policy. Chicago, IL: University of Chicago Press

Johnson, C. Donald. 2018. The Wealth of a Nation: A History of Trade Politics in America. New York: Oxford University Press 
Johnson, Willis Fletcher. 1889. History of the Johnstown Flood. Philadelphia, PA: Edgewood Publishing.

Johnstown Area Heritage Association. 1889 Flood Materials. https://www.jaha.org/about-jaha/archivesresearch/collections/1889-flood-resources/.

Kovacic, W. E. 2010. Dominance, Duopoly and Oligopoly: The United States and the Development of Global Competition Policy. Global Competition Review 14.

Krause, Paul. 1992. The Battle for Homestead, 1880-1892: Politics, Culture, and Steel. Pittsburgh: University of Pittsburgh Press.

Latham, Charles G. 1939. Benjamin Harrison in the Senate, 1881-87. Senior Thesis. Princeton University.

Maddison Project Database, version 2018. Bolt, Jutta, Robert Inklaar, Herman de Jong and Jan Luiten van Zanden. Rebasing 'Maddison': new income comparisons and the shape of long-run economic development. Maddison Project Working paper 10.

Markel, Howard. 1997. Quarantine!: East European Jewish Immigrants and the New York City Epidemics of 1892. Baltimore, MD: Johns Hopkins University Press.

Mayer, George H. 1964. The Republican Party: 1854-1964. New York: Oxford University Press.

Mccullough, David. 1987. The Johnstown Flood, Second Edition. New York: Simon \& Schuster.

McKnight Nichols, Christopher and Nancy C. Unger (eds). 2017. A Companion to the Gilded Age and Progressive Era. Malden, MA: John Wiley \& Sons, Inc., 2017.

Michener, Kris J. and Marc D. Weidenmier. 2008. The Baring Crisis and the Great Latin American Meltdown of the 1890s. The Journal of Economic History 68(2).

Moore, Anne Chieko. 2009. Benjamin Harrison: Centennial President. New York: Nova Science Publishers.

Morgan, James. 1969. Our Presidents: Chapters on Kennedy and Johnson. NY: Macmillan.

Morris, Edmund. 1979. The Rise of Theodore Roosevelt. New York: Random House.

National Quarantine Act of 1893

NBER Macrohistory Database. National Bureau of Economic Research. Boston, MA.

https://www.nber.org/databases/macrohistory/contents/

Newman, Patrick. 2018. Revenge: John Sherman, Russell Alger and the origins of the Sherman Act. Public Choice 174(3-4)

Officer, Lawrence H. 2011. "The Annual Consumer Price Index for the United States, 1774-2010,"

MeasuringWorth. http://www.measuringworth.com/

Olcott, Charles Sumner. 1916. The Life of William McKinley. Volume 1. Boston: Houghton Mifflin Company.

Oliphant, J Orin. 1932. Winter Losses of Cattle in the Oregon Country, 1847-1890. The Washington Historical Quarterly 23(1).

Palen, Marc-William. 2016. The "Conspiracy" of Free Trade: The Anglo-American Struggle over Empire and Economic Globalization, 1846-1896. New York: Cambridge University Press.

Peritz, Rudolph J.R. 2001. Competition Policy in America, 1888-1992. Oxford University Press 
Potter, Henry Codman. 1889. Address on the Centennial of George Washington's Inauguration, St. Paul's Church, New York. (April 30).

Pursell, Carroll W. Jr. 1962. Tariff and Technology: The Foundation and Development of the American Tin-Plate Industry, 1872-1900. Technology \& Culture. 3(3)

Reit, Steven P. 1998. Silver and Gold: The Political Economy of International Monetary Conferences Greenwood Press

Ringenberg, William C. "Benjamin Harrison: The Religious Thought and Practice of a Presbyterian President." American Presbyterians, 1986.

Rodabaugh, James H. 1935. Robert Hamilton Bishop. v.4. Columbus, OH: Ohio State Archaeological and Historical Society

Ross, Lewis W. 1892. (Illinois Congressman and schoolmate of Harrison). Quoted in Life and Public Services of Hon. Benjamin Harrison, President of the U.S. By Lew Wallace and Murat Halstead. Edgewood Publishing.

Sherman Antittrust Act of 1890

Sherman, John. 1895. John Sherman's Recollections of Forty Years in the House, Senate and Cabinet. Vol II. New York: The Werner Company.

Sievers, Harry J. 1959. Benjamin Harrison: Hoosier Statesman-From the Civil War to the White House, 18651888. Chicago: H. Regnery Co.

Sievers, Harry J. 1960. Benjamin Harrison: Hoosier Warrior, 1833-1865. Chicago: H. Regnery Co.

Sievers, Harry J. 1968. Benjamin Harrison: Hoosier President. Newtown, CT: American Political Biography Press.

Skocpol, Theda. 1992. Protecting Soldiers and Mothers: The Political Origins of Social Policy in the United States. Cambridge, MA: Belknap Press of Harvard University Press.

Skocpol, Theda. 1993. America's First Social Security System: The Expansion of Benefits for Civil War Veterans, Political Science Quarterly 108(85).

Socolofsky, Homer E. and Allan B. Spetter. 1987. The Presidency of Benjamin Harrison. Lawrence, KS:

University Press of Kansas.

Steeples, Douglas and David O. Whitten. 1998. Democracy in Desperation: The Depression of 1893. Westport, CT: Greenwood Press.

Stigler, George J. 1985. The Origin of the Sherman Act. The Journal of Legal Studies 14(1)

Taussig, Frank W. 1915. Some Aspects of the Tariff Question. Cambridge, MA: Harvard University Press.

Timberlake, Richard H. 1993. Monetary Policy in the United States: An Intellectual and Institutional History.

Chicago, IL: University of Chicago Press.

Tolliday, Steven. 2001. The Economic Development of Modern Japan, 1868-1945: From the Meiji Restoration to the Second World War. Edward Elgar Publishing.

US v. Workingmen's Amalgamated Council of New Orleans, 54 F. 994 (1893)

White, Richard. 2017. The Republic for Which It Stands. Oxford University Press. 
Williamson, Samuel H. 2019. Seven Ways to Compute the Relative Value of a U.S. Dollar Amount, 1790 to present.

Wirth, Max. 1893. The Crisis of 1890. Journal of Political Economy 1(2).

Wolfe, Thomas. 1934. Four Lost Men. Scribner's

Wolff, Leon. 1965. Lockout, The Story of the Homestead Strike of 1892. New York: Harper \& Row.

Woolley, John and Gerhard Peters. The American Presidency Project. UC Santa Barbara.

https://www.presidency.ucsb.edu/ 